\title{
Dom Helder Camara Profeta da justiça e Mensageiro da esperança
}

\author{
Dom Geraldo Lyrio Rocha
}

\section{Introdução}

Sinto-me imensamente honrado pelo convite que me foi dirigido pelo Pe. Jesus Hortal, Magnífico Reitor desta Pontifícia Universidade Católica do Reio de Janeiro, para proferir esta Aula Magna neste ano em que comemoramos o Centenário do Nascimento de Dom Helder Camara.

Seu nome está ligado a esta importante instituição, pois, Dom Helder foi um dos professores nos inícios da PUC - Rio, tendo aqui lecionado Filosofia. Em 1991, esta Universidade lhe outorgou o título de Doutor honoris causa.

Nesta comemoração do Centenário do Nascimento de Dom Helder, damos graças a Deus pelo dom de sua vida, repleta de sabedoria, profetismo e doação à Igreja e aos irmãos.

\section{Dados biográficos e traços pessoais}

\subsection{Origens e dados pessoais}

Dom Helder Pessoa Camara nasceu em Fortaleza, aos 07 de fevereiro de 1909. Foi o décimo primeiro filho do casal João Eduardo Torres Camara e Adelaide Rodrigues Pessoa Camara. Seu pai era guarda-livros e jornalista. Sua mãe era professora. Sua família era de poucas posses, porém culta e bem relacionada. ${ }^{1}$

\footnotetext{
${ }^{1}$ MARQUES, Luiz Carlos Luz - In Dom Helder Camara, Obras Completas, vol. I Tomo I, Editora Universitária UFPE, Recife, 2004, p. L.
} 
Aos 14 anos ingressou no Seminário da Prainha, em Fortaleza, onde fez seus estudos em preparação para o sacerdócio. Muitas vezes Dom Helder contou que, quando ele avisou para a família que queria ser padre, seu pai lhe advertiu: "meu filho, ser padre é coisa muito séria; padre e egoísmo não combinam". Com os padres lazaristas holandeses do Seminário, aprendeu que seu nome "Helder" significava: "sem nuvens, límpido, sem complicações". Era assim que ele queria ser.

Foi ordenado Sacerdote aos 15 de agosto de 1931, em Fortaleza. Aos 20 de abril de 1952, foi ordenado Bispo Auxiliar do Rio de Janeiro e a 02 de abril de 1955, recebeu o título de arcebispo. No dia 12 de abril de 1964, tomou posse como Arcebispo de Olinda e Recife. Com 76 anos, no dia 10 de abril de 1985, tornou-se Arcebispo emérito daquela Arquidiocese.

No dia 27 de agosto de 1999, com 90 anos de idade, Dom Helder partiu para o encontro definitivo com o Pai.

\subsection{Perfil humano e cristão}

Dom Helder era um poeta e possuía um temperamento artístico e, ao mesmo tempo, tinha um sentido vivo e profundo da realidade. Era um grande místico e, ao mesmo tempo, eminentemente prático e organizador. Era um homem de extrema simplicidade. Isto o credenciava a se aproximar dos mais simples e pobres e, ao mesmo tempo, sem se intimidar, se relacionava com ricos e grandes da sociedade. A todos sabia tratar com gentileza, amabilidade e distinção. Sabia escolher bem os seus colaboradores. Marcado por profunda humildade, recorria à colaboração de pessoas competentes e qualificadas. Gostava de ouvir a opinião de seus conselheiros e assessores e sabia trabalhar em equipe, valorizando a participação e contribuição de todos.

Um dos sinais que revelavam seu jeito simples e humilde era o seu hábito de almoçar quase todo dia em um boteco, perto do Palácio dos Manguinhos, onde lhe era servido um "prato feito". Ele nunca possuiu carro próprio. Andava na rua como um cidadão comum. Entre suas características destacam-se a eloqüência, a exuberância dos gestos, a sensibilidade em relação aos ouvintes e a expressão no modo de falar.

Tinha a arte de saber estabelecer grandes amizades. Possuía amigos por todo o mundo. Durante o Concílio, estabeleceu profunda amizade com o Cardeal Suenens, Arcebispo de Malinas e Bruxelas, um dos Moderadores do Concílio. Tornou-se também grande amigo do Rei Balduíno e da Rainha Fabíola da Bélgica.

Era surpreendente a multiplicidade de suas atividades e a diversidade de sua rica personalidade. Diz o Pe. Comblin: "Dom Helder era tudo, era a 
unidade dos contrários. Era profundamente místico e profundamente político. Unia perfeitamente contemplação e ação". ${ }^{2}$

Fascinado pela arte ele procurava acercar-se artistas, pintores, cantores, teatrólogos e outros intelectuais. Gostava de ir ao cinema quando sabia que um bom filme estava passando na cidade. Já se aproximava dos 80 anos de idade, quando compôs a letra e a arte da Sinfonia dos dois Mundos que ele mesmo apresentava e gostava e declamar.

Em seu livro Dom Helder Câmara - Profeta para os nossos dias, o Padre Marcelo Barros assim se exprime: "Uma das primeiras coisas que descobri em Dom Helder foi a veracidade interior e o forte cultivo de sua vida pessoal /.... Qual não foi minha surpresa ao descobrir, por trás da pessoa pública, um homem simples, frágil, que vivia suas buscas e inquietudes, e não as escondia". ${ }^{3}$ Quanto mais aumentava sua fama, tanto mais ele aprofundava sua humildade. Diz Marcelo Barros: "por trás daquele gosto pelos microfones e câmeras de TV, podíamos sempre apreciar um homem profundamente humilde. Gostava de se comparar com o burrinho que carregava Jesus na entrada de Jerusalém". ${ }^{4}$

Embora fosse de muita ação, era também de profundo espírito de oração. Dom Helder diariamente se levantava às duas e meia da madrugada para sua longa vigília de oração, meditação, reflexão. Nessas horas escrevia suas poesias, discursos e pronunciamentos. O eixo principal da vigília era o encontro profundo consigo mesmo e com o Senhor. Ele dizia: "O que seria de mim, sem este tempo de reabastecimento interior? Quando o céu toca na terra, podemos conversar sobre todos os problemas dos homens e sobre todos os mistérios de Deus". ${ }^{5}$ Sobre essa sua experiência, Dom Helder escreveu: "Durante a minha vigília, procuro reconstruir a unidade em Cristo. Com ele, revivo os encontros do dia anterior". 6

Amava profundamente a Eucaristia. Sua maneira de celebrar a Santa Missa impressionava a todos. Com muita freqüência chegava até mesmo a chorar durante a celebração. Sabia ligar a missa que celebrava com o dia-a-dia que vivia. Expressava a firme convicção de que o mesmo Cristo presente na Eucaristia se encontra na pessoa do pobre, marginalizado e sofredor. "Para ele, o rosto do outro era o rosto dos milhões de oprimidos nos quais ele via sempre o rosto de Cristo". ${ }^{7}$

\footnotetext{
${ }^{2}$ COMBLIN, José - In Dom Helder Câmara - Profeta para os nossos dias, Ed. Rede da Paz, 2006, p. 9

${ }^{3}$ BARROS, Marcelo - Dom Helder Camara - Profeta para os nossos dias, Ed. Rede da Paz, 2006, p. 51

${ }^{4}$ Id. Ib. - p. 71

${ }^{5}$ Id. Id. - p. 66

${ }^{6}$ CAMARA, Helder - Il vangelo com Dom Helder, Assisi, Citadella Editrice, 1988, p. 11

${ }^{7}$ BARROS, Marcelo - op. cit. p. 98
} 
A Irmã Catarina Damasceno, que durante 24 anos viveu, trabalhou e se dedicou aos pobres de rua, ao lado de Dom Helder, dá esse comovente testemunho: "Dom Helder, além de profeta, era um homem de oração profunda e constante. Vivia mergulhado em Deus. Sua sensibilidade ao sofrimento dos pobres e oprimidos ultrapassava todos os limites". 8

Não tinha medo de enfrentar as questões, mesmo as mais polêmicas. Isso fez com que fosse muito admirado e querido por uns e odiado e até perseguido por outros. No silêncio, amargou incompreensões, difamações e perseguições tanto por parte do governo militar brasileiro, como por parte de setores da mídia e, até mesmo, de irmãos incomodados com sua atitude e palavra profética.

Podemos sintetizar os traços de seu perfil humano e cristão com suas próprias palavras: "Gostaria de ser apenas uma simples poça de água que refletisse o céu". 9

\subsection{Místico e organizador}

Desde o tempo de seminarista, envolveu-se na formação e fortalecimento de movimentos católicos tais como a Legião Cearense do Trabalho, os Círculos Operários, a Juventude Operária Católica (JOC), a Sindicalização Operária Católica Feminina, a Liga dos Professores Católicos do Ceará e a Liga Eleitoral Católica. "Atraído pelo integralismo, recebe autorização para tornar-se membro do novo parido, e é como representante desse que assume a Diretoria da Instrução Pública do Estado do Ceará", 10

O próprio Dom Helder assim se expressa a respeito de seu envolvimento com o integralismo: "Eu sai em 1937, antes da guerra e antes de todo o horror do holocausto. Percebi que estava errado e me converti. Percebi que o mundo não se divide verdadeiramente em direita e esquerda e sim entre o mundo dos mais ricos e o mundo da imensa multidão de pobres. Até hoje encontro pessoas que continuam com aquela visão maniqueísta da vida que eu tinha até 1937 e mudei de pensamento. Aliás, em toda a minha vida, sempre tenho seguido este princípio: Só não muda de pensamento quem não tem pensamento para mudar. Eu penso, por isso mudo... E quero continuar mudando sempre... ${ }^{11}$

\footnotetext{
${ }^{8}$ DAMASCENO, Catarina - Mil Sementes Caídas e Algumas Apanhadas, FASA Gráfica, 2007, p. 55

${ }^{9}$ CAMARA, Helder - Mille ragione per vivere, Assisi, Citadella Editrice, 1980, p. 31

${ }^{10}$ MARQUES, Luiz Carlos Luz - op. cit. p. LI

${ }^{11}$ BARROS, Marcelo - op. cit. p. 108
} 
Logo após sua ordenação, além das atividades sacerdotais, dedicou-se à educação e também ao movimento operário. Com poucos anos de sacerdócio, Padre Helder "desiludido com a política e o poder, abalado pela morte da mãe e perseguido por calúnias, parte para o Rio de Janeiro, no início de $1936 "{ }^{12} \mathrm{Na}$ então capital da República, realizou sua missão durante 28 anos, com abundantes e excelentes frutos. No início, Padre Helder trabalhou, sobretudo, no campo da educação. Durante muitos anos, atuou no Conselho Nacional de Educação. Depois, dedicou-se a outras atividades pastorais.

Como assistente nacional da Ação Católica especializada, Pe. Helder tornou-se grande incentivador da formação de um laicato maduro, a serviço do Reino de Deus. Promoveu as Semanas Sociais que reuniam Bispos, presbíteros, religiosos(as), leigos(as) para debater os grandes problemas nacionais daquele momento.

No Rio de Janeiro, foi diretor do serviço de Medidas e Programas de Educação (1936); diretor do Ensino de Religião da Arquidiocese; redator chefe (1949) e depois diretor da Revista Catequética (1951); diretor da Revista do Assistente Eclesiástico (1947 - 1952).

Entre suas atividades mais importantes como bispo auxiliar da Arquidiocese do Rio de Janeiro destacam-se: organizador e secretário geral do XXXVI Congresso Eucarístico Internacional (1955); atuou ativamente na preparação da I Conferência Geral do Episcopado Latino Americano que se realizou no Rio de Janeiro (1955); fundador da Cruzada São Sebastião (1956); fundador do Banco da Providência (1959).

\section{Dom Helder e a renovação da Igreja}

\subsection{Participação na vida da Igreja no Brasil e na América Latina}

Dom Helder contribuiu de maneira decisiva para a renovação da Igreja no Brasil e influenciou também a vida da Igreja na América Latina: organizou a educação católica, dinamizou a Ação Católica brasileira, idealizou e organizou a Conferência Nacional dos Bispos do Brasil (CNBB) e teve participação ativa na fundação do Conselho Episcopal Latino americano (CELAM).

Como bispo, Dom Helder exerceu muitas funções: Assistente nacional da Ação Católica (1952-1962); Secretário geral da CNBB (1952-1964); fundador da Cáritas Brasileira (1956); Secretário de Ação Social da CNBB (1964-1968); Presidente da Comissão Brasileira de Migração; Presidente do

\footnotetext{
${ }^{12}$ MARQUES, Luiz Carlos Luz - op. cit. p. LI.
} 
Regional Nordeste II; Membro da Comissão Representativa da CNBB; delegado do Brasil junto ao CELAM (1958-1960); Segundo Vice-Presidente do CELAM (1960-1964); delegado da CNBB à Assembléia Geral do Episcopado Latino Americano, em Medellín (1968).

Foi conselheiro da Nunciatura Apostólica no Brasil, desde 1949. No exercício dessa função, exerceu grande influência na indicação de candidatos ao episcopado.

Entre as muitas contribuições de Dom Hélder à Igreja no Brasil, sem dúvida, destaca-se seu papel na CNBB. Foi ele o idealizador da Conferência Nacional dos Bispos do Brasil - CNBB, dez anos antes do Concílio Vaticano II. Em 1952, ele consegue a permissão da Santa Sé para a criação da Conferência dos Bispos do Brasil. "No dia 14 de outubro de 1952, no Rio de Janeiro, Capital da República, numa sala do palácio São Joaquim, os vinte arcebispos do Brasil de então, presentes ou representados, fundaram a Conferência Nacional dos Bispos do Brasil (CNBB), aprovaram seu pequeno 'regulamento', elegeram-lhe a Comissão Permanente que, por sua vez, escolheu o cardeal Carlos Carmelo de Vasconcelos Motta, de São Paulo, para primeiro presidente. Este indicou D. Helder Camara para secretário geral, sendo eleito por aclamação". "Foi ele o redator da ata de fundação da Conferência Nacional dos Bispos do Brasil.

Como Secretário Geral da CNBB, por 12 anos, Dom Helder teve extraordinária atuação, dando-lhe o perfil que perdura até hoje. Entre as muitas atividades podem ser destacadas: As reuniões de bispos das grandes regiões do país, que são como o embrião dos Regionais em que depois se dividiu a CNBB. Liderou um grupo de bispos que apoiavam iniciativas voltadas para a transformação social, tais como Reforma Agrária, Escolas Radiofônicas, Movimento de Educação de Base, entre outras. Coordenou a preparação do Plano de Emergência (1962) e iniciou os estudos que deram origem ao Plano de Pastoral de Conjunto - PPC, aprovado pela CNBB, em Roma, ao término do Concílio Ecumênico Vaticano II (1965).

Em 1955, por ocasião do Congresso Eucarístico Internacional do Rio de Janeiro, participou ativamente na fundação do Conselho Episcopal Latino Americano (CELAM), juntamente com Mons. Manuel Larraín, Bispo de Talca, no Chile. Foi delegado do Brasil junto ao CELAM (1958-1960) e exerceu a função de Segundo Vice-Presidente desse organismo durante o mandato de 1960 a 1964.

\footnotetext{
${ }^{13}$ QUEIROGA, Gervásio Fernandes de - DA CNBB AO VATICANO II: Dom Helder e a busca constante de colegialidade e comunhão - In Revista de Teologia e Ciências da Religião, n. 7,2008, p. 55
} 
$\mathrm{Na}$ Conferência de Medellín, trabalhou intensamente pela defesa dos negros e indígenas. Ele é o inspirador do texto que se encontra no documento 5 da Conferência de Medellín: "Que se apresente, na América Latina, cada vez mais nítido, o rosto de uma Igreja autenticamente pobre, missionária e pascal, desligada de todo o poder temporal e comprometida com audácia na libertação do homem todo e de todos os homens" (MEDELLÍN Documento 5, n. $15^{\mathrm{a}}$ ).

Exerceu também várias funções junto à Santa Sé: Membro do Conselho de Imigração; Na fase preparatória do Vaticano II, foi consultor da Comissão intitulada 'Bispos e governo das Dioceses' e Membro da 'Comissão para a Disciplina do Clero'; delegado da CNBB ao III Sínodo dos Bispos (1974).

\subsection{Pastoreio na Arquidiocese de Olinda e Recife}

Em 1964, doze dias após o golpe militar, Dom Helder assumia o pastoreio da Arquidiocese de Olinda e Recife, tendo a seu lado o admirável Bispo Auxiliar, Dom José Lamartine Soares. Dom Helder vai se firmando, sempre mais, como grande profeta, cuja palavra repercute para além de sua Arquidiocese e vai ecoar em todo o Brasil, em outros países da America Latina e chega até as diversas partes do mundo.

Dois fatores significativos acentuavam a importância fundamental da presença de Dom Helder naquele momento no Nordeste do brasileiro: no campo sócio-polítco, o regime militar implantado em 1964, cuja face ditatorial se tornava cada vez mais rígida e autoritária; no campo eclesial, o Concílio Ecumênico Vaticano II, com sua extraordinária perspectiva de renovar a Igreja diante dos grandes desafios dos tempos atuais.

Dom Hélder chega a Recife, trazendo consigo uma bagagem de ricas experiências acumuladas. Assume o pastoreio dessa porção do Rebanho do Senhor, desejoso de ser fiel aos apelos da Igreja e ao sopro do Espírito no meio de um povo que espelha o rosto do Cristo Sofredor. Na mensagem, por ocasião de sua chegada à Arquidiocese de Olinda e Recife, Dom Helder dirigiu ao seu povo uma saudação permeada de liberdade evangélica: "Quem sou eu e a quem estou falando ou desejando falar? - um nordestino falando a nordestinos, com os olhos postos no Brasil, na América Latina e no mundo. Uma criatura humana que se considera irmão de fraqueza e de pecado dos homens de todas as raças e de todos os cantos do mundo. Um cristão se dirigindo a cristãos, mas de coração aberto, ecumenicamente, para os homens de todos os credos e de todas as ideologias. Um Bispo da Igreja Católica que, à imitação de Cristo, não vem para ser servido, mas para servir...". 
Esta mensagem estava toda ela embebida de sabor profético, de teor missionário. Apresenta-se como o bispo de todos ao explicitar sua postura pessoal e suas prioridades: "Ninguém se escandalize quando me vir freqüentando criaturas tidas como indignas e pecadoras. Quem não é pecador? Quem pode jogar a primeira pedra? Nosso Senhor, acusado de andar com publicanos e almoçar com pecadores, respondeu que justamente os doentes é que precisam de médico. Ninguém se espante me vendo com criaturas tidas como envolventes e perigosas, da esquerda ou da direita, da situação ou da oposição, anti-reformistas ou reformistas, anti-revolucionárias ou revolucionárias, tidas como de boa ou de má fé. Ninguém pretenda prenderme a um grupo, ligar-me a um partido, tendo como amigos os seus amigos e querendo que eu adote as suas inimizades. Minha porta e meu coração estarão abertos a todos, absolutamente a todos. Cristo morreu por todos os homens: a ninguém devo excluir do diálogo fraterno".

Alguns dos passos desta trajetória missionária, nas duas décadas em que Dom Hélder exerceu a missão como Arcebispo de Olinda e Recife (1964 a 1985), expressam a ebulição pastoral do momento, como busca de resposta aos apelos da Igreja do Concílio Vaticano II.

As linhas mestras da evangelização na Arquidiocese de Olinda e Recife explicitavam a criatividade impulsionada pelo Concílio Vaticano II: a valorização dos cristãos leigos(as) como mensageiros de esperança nos respectivos campos de atuação; a criação do Movimento de Evangelização Popular, chamado "Encontro de Irmãos", que agrupou milhares de cristãos especialmente dos bairros pobres; as mais de 400 Comunidades Eclesiais de Base (CEBs) na arquidiocese; a Operação Esperança para atender aos flagelados das chuvas no grande Recife; o apoio total à atuação da Comissão de Justiça e Paz, sobretudo preocupada com as comunidades populares e com os numerosos presos políticos; a criação do Instituto de Teologia do Recife (ITER) para formar os Ministérios diversificados na perspectiva do trabalho eclesial; a presença contínua nas paróquias, o incentivo a movimentos para levar o Evangelho às classes médias da cidade. $\mathrm{O}$ ideal apresentado por Dom Helder ao chegar a Recife, foi largamente concretizado na busca de uma Igreja missionária e profética.

Como Arcebispo de Olinda e Recife, desenvolveu várias atividades e levou adiante diversas iniciativas: fundou o Banco da Providência (1964); a Operação Esperança (1965); as Obras de Frei Francisco (1984); a Casa de Frei Francisco (1984); o Centro de Documentação (1999) e criou 19 paróquias. Seu ministério episcopal foi marcado pelos sentimentos de Jesus que "vendo numerosa multidão, teve compaixão, porque eram como ovelhas sem pastor" (cf. Mc 6,30-34). 
Logo que chegou a Recife, Dom Helder decidiu que não iria morar no Palácio dos Manguinhos, antiga residência episcopal. Com a ajuda de pessoas de Recife, procurou um lugar pobre e discreto para residir. Só após quatro anos é que conseguiu realizar esse seu desejo e foi se estabelecer nas dependências da Igreja das Fronteiras, junto à comunidade das Filhas da Caridade.

\subsection{Atuação no Concílio Vaticano II}

Assim que recebeu a consulta que, em nome do Papa João XXIII, o Secretário de Estado dirigiu a todos os bispos e prelados do mundo, solicitando suas sugestões para a agenda conciliar, Dom Helder apressou-se a enviar sua resposta, com data de 15 de agosto de 1959.

Sugere várias comissões que se ocupassem dos distintos problemas e sob o título de "Por uma situação mais feliz do mundo", propõe que a matéria conciliar fosse agrupada em seis grandes áreas: economia, artes, ciências, política, questões sociais e questões religiosas.

Enquanto muitos falam do conflito entre as grandes potências do Oriente e do Ocidente no quadro da guerra fria, Dom Helder propõe que o Concílio volte sua atenção para os $2 / 3$ da humanidade que estão submersos na fome e na miséria. Propõe que as igrejas situadas nos países mais ricos da América (Canadá e Estados Unidos) se empenhassem numa ação conjunta com os demais países da América Latina e do Caribe para superar a grave situação do continente. Pensa, entretanto, que a mesma preocupação deveria estender-se aos povos empobrecidos da Ásia e da África.

Como participante do Concílio Vaticano II (1962-1965) integrou a Comissão para o Apostolado dos Leigos e Meios de Comunicação Social, encarregada de redigir um esquema sobre as relações entre a Igreja e o mundo contemporâneo que deu origem à Constituição Pastoral Gaudium et Spes.

Assim se expressa o Pe. José Oscar Beozzo: "Dom Helder, secretário da CNBB e vice-presidente do CELAM, lançou-se, de corpo e alma, junto com Dom Manoel Larrain, seu colega na vice-presidência do CELAM, no esforço de articulação com as demais conferências episcopais, para comporem a nova lista de nomes para as Comissões Conciliares, em substituição às Comissões da fase preparatória que a Secretaria Geral do Concílio, queria ver transformadas nas Comissões permanentes do próprio Concílio. Isto perpetuaria o controle que a Cúria Romana havia exercido sobre toda a etapa de preparação do Concilio. Começava ali sua singular aventura, durante os quatro anos do Concílio Vaticano II (1962 a 1965), que o transformariam, do relativamente pouco conhecido arcebispo auxiliar do Rio de 
Janeiro, num dos personagens mais influentes na cena internacional da Igreja contemporânea". ${ }^{14}$

Com sua extraordinária capacidade de articulação, Dom Helder atuou em diversos grupos de bispos de várias partes do mundo que ofereceram importantíssimas contribuições ao Concílio. "Em comum acordo com o então cônego Etchegaray, secretário do episcopado francês, promoveu encontro sistemático de secretários de Conferências Episcopais, formando um grupo que ele mesmo chama de Ecumênico". ${ }^{15}$ Esse grupo teve especial papel na eleição para completar as comissões, que se realizou na segunda sessão conciliar, em novembro de 1963.

Importante também foi a atuação de Dom Helder junto ao grupo que se reunia no Colégio Belga, conhecido como o 'Grupo da Pobreza' ou da 'Igreja dos pobres' mas que Dom Helder preferia chamar de 'Grupo da Igreja servidora e pobre'. Vários bispos brasileiros participaram desse grupo que firmou o famoso 'Pacto das Catacumbas'. Ao final do Concílio, no dia 16 de novembro de 1965, quarenta bispos de várias partes do mundo reuniram-se numa catacumba em Roma e assinaram um Pacto. Cada um assumia o compromisso de viver pobre, rejeitar as insígnias, símbolos e privilégios do poder e a colocar os prediletos de Deus no centro de seu ministério episcopal, explicitando assim a evangélica opção pelos pobres.

Dom Helder não falou nem uma vez na Aula Conciliar. Mas, apresentou, por escrito, várias intervenções notáveis que foram entregues diretamente à Secretaria Geral do Concílio. Nelas transparece sua preocupação com os rumos do Concílio e com seu método de trabalho. Em todas elas, deixa clara sua visão frente aos grandes problemas contemporâneos e as responsabilidades e missão da Igreja. Sua grande tribuna no Concílio, não foi a Aula Conciliar na Basílica de São Pedro, mas sim a imprensa. Durante o Concílio, muitas idéias apresentadas pelo Cardeal Suenens, "tinham sua origem na imaginação fecunda de Dom Helder". ${ }^{16}$

O Pe. José Oscar Beozzo afirma: "Outro feito decisivo de D. Helder Camara no Concilio foi conseguir que os melhores teólogos e peritos ali presentes começassem a trabalhar em conjunto. Esse mesmo grupo de teólogos prestou inestimável serviço aos bispos do Brasil, por meio das conferências da Domus Mariae, que na soma das três últimas sessões alcançaram

\footnotetext{
${ }^{14}$ BEOZZO, José Oscar - Dom Helder Câmara e o Concílio Vaticano II, Conferência, Cuernava, 2002, p. 3

${ }^{15}$ MARQUES, Luiz Carlos Luz - op. cit. p. XLV.

${ }^{16}$ COMBLIN, José - In; Dom Helder Câmara - Profeta para os nossos dias, Ed. Rede da Paz, 2006, p. 8
} 
o respeitável número de 84 , às quais devem ser acrescentadas outras dez da primeira sessão". ${ }^{17}$

\section{Esperando contra toda esperança $(\mathrm{Rm} 4,18)$}

\subsection{O período da ditadura militar}

Durante o regime militar, Recife torna-se um dos campos de numerosas prisões por motivos políticos. Como em outras partes de nosso País, em Recife o clima de medo invadia a população e a repressão atingia as lideranças que não se dobravam diante da ditadura.

Para o regime militar, eram já conhecidas as posições de Dom Helder, tanto pela sua atuação na cidade do Rio de Janeiro, como pelos seus posicionamentos em nível nacional, especialmente na defesa dos direitos dos pobres, na promoção da justiça, da democracia e da liberdade de expressão.

Seus pronunciamentos, homilias e iniciativas pastorais incomodavam o regime militar que o condenou, em 1970, a ser silenciado pelos meios de comunicação de todo o País. Um Ofício dos militares que assumiram o Poder, dirigido a todos os órgãos de comunicação, os proibia de falar a favor ou contra Dom Helder. Não podiam mesmo citar o seu nome. O próprio Dom Helder afirmava: "decretaram que eu não mais existia".

Um dos fatos que lhe trouxe maior sofrimento foi o assassinato do padre Antônio Henrique Pereira Neto, a 27 de maio de 1969, praticado pelas forças da repressão. Era ele um jovem sacerdote que trabalhava na pastoral da juventude estudantil. O trágico acontecimento queria atingir a Arquidiocese de Olinda e Recife e o seu Arcebispo.

\subsection{Opção pelos pobres e luta pela justiça}

Durante o Vaticano II, Dom Helder soube aproveitar a oportunidade dos contatos com todos os Episcopados do mundo. Esse papel singular que soube desempenhar durante o Concílio lhe oferecia a possibilidade de tornarse missionário do mundo, como peregrino da justiça e da paz.

Um relacionamento especial de amizade ele travou imediatamente com os Bispos que tinham maior sensibilidade para a problemática do "Terceiro Mundo". Desde a década de 50, Dom Helder já buscava se cercar de peritos que pudessem ajudá-lo a enfrentar o grande desafio da miséria da humanidade que tanto lhe preocupava. Entretanto, realizou um grande per-

\footnotetext{
${ }^{17}$ BEOZZO, José Oscar - op. cit. p. 8
} 
curso em sua maneira de concretizar a opção pelos pobres. Sua atitude inicial tinha uma característica mais assistencialista. Mas, já nessa época, ele defendia a urgência de uma reforma agrária para refrear o êxodo rural que vinha provocando o crescimento das periferias urbanas e o aumento das favelas nas grandes cidades. Aos poucos ele foi adquirindo uma visão mais educadora. Da busca de ajuda dos governantes e poderosos, ele passa a compreender que só os pequenos organizados é que podem realizar a verdadeira transformação de forma justa e pacífica. Logo percebeu que a pobreza no mundo não nasce por geração espontânea, mas é fruto da dominação que divide o mundo entre o Norte rico e o Sul explorado.

Com vigor profético, repetia sempre sua mensagem fundamental: "Mais de dois terços da humanidade se encontram em condições infrahumanas de miséria e fome. São condições indignas até para animais. Isso acontece por vários fatores, mas se mantém porque $20 \%$ da humanidade, a parte rica do mundo, absorve $80 \%$ dos recursos da terra e os $80 \%$ restantes da humanidade devem se contentar com a migalha de 20\% dos mesmos recursos. Nada de importante mudará no mundo se não conseguirmos mudar isso". ${ }^{18}$

Consciente de que sua missão episcopal não se esgotava somente no pastoreio da Igreja particular de Olinda e Recife, Dom Helder busca irradiar confiança e dirigir uma palavra que possa sedimentar a mística do compromisso evangélico com a causa da justiça que gera a paz e reanima a esperança. Mesmo sendo sinal de contradição, nunca deixou de ser mensageiro da esperança, sobretudo para os mais pobres. Diante do primeiro mundo, procura ser a voz dos sem voz do terceiro mundo.

Muitas vezes foi injustamente acusado de instigar a luta de classes. Ele sofria com isso, e muitas vezes repetiu: "Se eu dou comida aos pobres, chamam-me de santo. Se eu pergunto por que os pobres não têm comida, chamam-me de comunista". ${ }^{19}$ Entretanto, ele acreditava que uma verdadeira ação transformadora teria de se dar por meio da não-violência ativa, o que muitos marxistas ortodoxos não aceitavam.

Já na primeira mensagem à Arquidiocese de Olinda e Recife, Dom Hélder dizia a que vinha e expunha; expõe sua opção pelos pobres dentro da tradição latino-americana: "De nada adiantará venerarmos belas imagens de Cristo, digo mais, nem bastará que paremos diante do Pobre e nele reconheçamos a face desfigurada do Salvador, se não identificarmos o Cristo na criatura humana a ser arrancada do subdesenvolvimento. Por estranho que a alguns pareça, afirmo que, no Nordeste, Cristo se chama Zé, Antônio,

\footnotetext{
${ }^{18}$ BARROS, Marcelo - op. cit. p. 75

${ }^{19}$ Id. Ib. - p. 116
} 
Severino... "Ecce Homo": Eis o Cristo, Eis o Homem! Ele é o homem que precisa de justiça, que tem direito à justiça, que merece justiça".

\subsection{Peregrino da paz e da esperança}

Se por um lado, a atitude dos militares limitava sua ação de pastor diocesano, por outro lado, o lançava na missão profética além das fronteiras do Brasil, com convites insistentes para fazer conferências em muitas partes do mundo. Chegou a receber mais de 80 convites por ano para conferências em diversas nações.

Em plena ditadura militar, nos meados dos anos 60, Dom Helder sonhou em criar o movimento de não-violência, em escala mundial, que congregasse pessoas de diferentes credos religiosos para lutar pacificamente por mudanças estruturais e pelo fiel cumprimento da Declaração Universal dos Direitos Humanos. Começou então a articular um movimento internacional ao qual chamou de Ação Justiça e Paz.

No plano nacional e internacional, Dom Helder promoveu, estimulou e fundou vários movimentos marcados por seu espírito profético. Já no começo da década de 50, inspirado em uma iniciativa alemã, ele estimulou o surgimento de um movimento que visava organizar a caridade em nível internacional. Dom Helder foi um dos inspiradores da Caritas Internacional e do surgimento da Comissão Justiça e Paz. Criou o Movimento de Articulação das Minorias Abrâmicas. Ao aproximar-se o novo milênio, lançou a proposta do 'Ano 2000 sem miséria'.

No início da década de 60, Dom Helder começa a viajar pelo mundo com o intuito de convencer especialmente os responsáveis pelas estruturas políticas, econômicas e religiosas a se preocuparem com a urgente necessidade de se promover uma ação concreta em vista do desenvolvimento humano e integral. Ele afirmava com vigor: "Para deter a catástrofe (da fome e da miséria de dois terços da humanidade), é preciso reorganizar as relações entre as sociedades e entre os países. É preciso reformar as estruturas internacionais do comércio. É preciso inventar uma nova ordem econômica internacional. Vocês sabem que essa é a idéia: a estratégia do desenvolvimento integral. Mas, percebe-se cada vez mais que isso é dificil porque é dificil conseguir que haja vontade política para isso por parte dos que mandam". 20

Dom Helder tinha como lema missionário o versículo da carta de São Paulo aos romanos: "esperando contra toda esperança, como Abraão" (Rm

${ }^{20}$ Id. Ib. - p. 77 
4,18). Para tanto, em suas viagens internacionais, estimulava as minorias abraâmicas, semeando grupos em todos os continentes. As minorias abrâ̂micas eram formadas por aquelas pessoas que esperavam, apesar dos pesares, com firmeza permanente, se comprometendo com a construção de uma sociedade justa e fraterna. Era a não violência ativa.

\section{Atividades, funções e títulos honoríficos}

\subsection{Participação em Entidades nacionais e internacionais}

A Ir. Catarina Damasceno nos transmite uma acurada relação das atividades exercidas por Dom Helder, no Brasil e no exterior, e dos títulos honoríficos e condecorações que recebeu em várias partes. ${ }^{21}$

Dom Helder sempre foi um homem de muita atividade e grandes iniciativas. No Brasil, participou ativamente na criação da SUDENE e do Movimento de Educação de Base - MEB. Foi membro Fundador do Centro Brasileiro de Cooperação e Intercâmbio de Serviços Sociais - Rio de Janeiro (1962); Membro do Conselho Científico do Instituto Materno-Infantil de Pernambuco - Recife (1987); Membro do Comitê de honra da Solidariedade França-Brasil - Rio de Janeiro (1989); Sócio da União Brasileira de Escritores - Recife (1989) e Membro do Colégio de Mentores - Fortaleza (1990).

Foi membro de mais de 40 entidades internacionais: Membro do Comitê de honra da Organização Internacional "Justice e Developpement" França (1968); Membro do Comitê do Instituto de Viena para o Desenvolvimento - Áustria (1970); Membro do Curatorium do Conselho Científico do SIPRI - Suécia (1970); Membro do Curatorium do Centro Albert Schweitzer - Alemanha (1971); Membro da Conferência Mundial de Religião pela Paz - Neva York - USA (1971); Membro de honra da Societé Allemande pour la Paix - Alemanha (1971); Membro do Conselho Acadêmico da Universidade da Paz - Bélgica (1971); Membro do Consejo Consultivo Internacional de la Fondación del Hombre - Buenos Aires - Argentina (1971); Membro do Comitê de Diretores do Conselho Mundial de Igrejas Nova York - USA (1973); Membro do Curatorium 'Les Amis de la Pax Christi International' - Bélgica (1975); Membro pleno do Fórum do Terceiro Mundo - México (1977); Membro do Clube de Dakar (1978); Membro de honra da Fondation Mondiale de Jeunesse Caholique - Bélica (1978); Membro de honra da Association des Amis du Père Riobé - França (1979); Membro Consultivo Internacional da Revisa Gandhi Marg da Gandhi Peace

${ }^{21}$ DAMASCENO, Catarina - op. cit. p. 98 
Foundation - New Delhi - Índia (1979); Um dos nove vice-presidentes do Worldiew International Foundation -WIF - Siri Lanca (1980); Membro fundador das Journées Universitaires de la Paix - Bélgica (1980); Membro da Nacional Geografic Society - USA (USA (1981); Membro do Conselho Executivo do Nonviolent Alternatives - Bélgica; Membro do Conselho Diretor da Associação Latino-americana para os Direitos Humanos - Equador; Membro da Música Esperança - Buenos Aires - Argentina (1982); Membro do Conselho do International Center for Integrative Studies - USA (1983); Membro do Comitê de honra da Foundation Internacional pour la promocion des Droits de l'Homme par l'audiovisual - França (1983); Membro titular da Academie Internacional de Prospective Social - Suíça (1983); Membro do Comitê do Premier Fesival d'Animation Culturale - Paris - França (1984); Membro do Comitê Bertrand Russel - Amsterdam - Holanda (1985); Membro do Comitê de Parranaige de Congrés Institut African des Droits de l'Homme - Dakar - Senegal (1986); Membro do Comitê de honra do The Dana McLean Greeley Foundation for Peace and Justice - USA (1986); Membro do comitê científico do Centro di Studi e di Formazione su i Diritti dell'Uomo i dei Popoli - Università degli Studi di Padova - Itália (1986); Membro do comitê de honra para l'Organisation du Colloque Albert Memmi - Paris (1986); Membro de honra do International Holistic University - Paris - França (1986); Member of International Committee "The Temple of Undersanding" - New York - USA; Membro do Comitê de Parrainage Sophia Antipolis - França - (1989); Membro associado do Comitê de Expertos para a prevenção da tortura nas Américas - Montevidéu - Uruguai (1989); Membro do Consiglio Cientifico Internazionalde (Forum on the Problems of Peace and War) - Florença - Itália (1989); Membro do Conselho "Credo Internacional" - USA (1991); Membro do Comitè Catholique Contre la Faim et pour le Développement - Forum Terre d'Avenir - Paris - França (1992); Sócio fundador da Fundación Raúl Silva Henriques - Santiago - Chile (1996); Membro do Harvard Alumi - Massachusetts - USA (1997).

\subsection{Publicações}

Dom Helder publicou mais de 20 livros, entre os quais: Revolução dentro da Paz (1968); Terzo Mondo defraudato (1968); Spirale de Violence (1970); Pour arriver à temps (1970); Le désert est fertile (1971); Prière por les riches (1972); Um olhar sobre a cidade (1 $1^{\mathrm{a}}$ Ed.1976 - 6 edições); Les Conversiones d'un Evêque (1977); Mil razões para viver (1 $1^{\text {a }}$ Ed. $1978-7$ edições); Renouveau dans l'Esprit et Service de l'Homme - Card. Léon Joseph Suenens (1979); Mille raison pour vivre (1980); Nossa Senhora no meu 
caminho ( $1^{\text {a }}$ Ed. 1981 - 5 edições); Hoffer wider alle hoffnung (1981); Des questions pour vivre (1984); L'Evangile avec Dom Helder (1985); Em tuas mãos, Senhor! (1986); Quem não precisa de conversão? (1987); Utopias Peregrinas (1993); Palavras e Reflexões (1995); Rosas para meu Deus (1996); Família, missão de amor (1997); Ano 2000 - 500 anos de Brasil: uma visão de fé, esperança e amor nas mensagens de Dom Helder Câmara (1999).

\subsection{Condecorações e titulos honorificos}

Muitas foram as condecorações e os títulos honoríficos que recebeu como expressão do reconhecimento por sua importante atuação na Igreja e na sociedade. Cerca de 30 cidades lhe concederam o título de cidadão honorário.

Recebeu 25 Prêmios: Prêmio René Sende, de Serviço Social - Rio de Janeiro (1962); Prêmio Memorial Juan XXIII - VII aniversário da Pacem in Terris - Seção Espanhola da Pax Christi (1970); Prêmio Martin Luther King - Atlanta - USA (1970); Prêmio da Paz, com o título "O Homem do Terceiro Mundo - Viareggio - Itália (1970); Prix Hammarskjoeld - Patrocínio da Organisation Mondiale de la Presse Diplomatique (1973); Prêmio Popular da Paz - Noruega (1974); Prêmio Melhor Escritor sobre os problemas do Terceiro Mundo - Caliari - Itália (1974); Prêmio São Francisco - North American Federation Third Order of S. Francis - Ohio - USA (1975); Prêmio Voice of Justice - Indiana - USA (1975); Prêmio Pacem in Terris - Indiana USA (197); Prêmio da Paz Victor Gollancz Humanity Award - LondresInglaterra (1975); Prêmio Thomas Merton - Pittsburg - Pensilvânia - USA (1976); Prêmio Artesãos da Paz - Itália (1982); Prêmio Ordine al Merito della Pace - Astti - Itália (1982); Prêmio Mahatma Ghandi - São Paulo Brasil; Prêmio Niwano Peace Prize - Tóquio - Japão (1983); XIII Prêmio Internazionale della Testimonianza - Itália (1985); Premio Raoul Follereau Roma - Itália (1986); Prêmio Roma-Brasília Cidade da Paz - Roma - Itália (1986); Prêmio Chistopher Award for 1987 - USA (1987); Prêmio Nutrição - Troféu Nelson Chaves - Recife - Brasil (1988); Prêmio Heleno Fragoso Curitiba - Brasil (1992); Prêmio Paul VI - Teacher of Peace a Ward - USA (1992); Prêmio UNIPAZ - Brasília - Brasil (1997).

Foi-lhe conferido o título de Doutor honoris causa por mais de $30 \mathrm{U}$ niversidades de várias partes do mundo. Entre elas: Saint Louis - USA (1969); Louvain - Bélgica (1970); Santa Cruz - Massachusetts - USA (1970); Friburgo - Suíça (1971); Münster - Alemanha (1972); Havard USA (1974); Sorbone - Paris - França (1975); Cincinati - USA (1975); 
Universidade Livre de Amsterdam - Holanda (1975); Notre Dame - Indiana - USA (1976); Universidade de Florença - Itália (1977); Manhattan - Nova York (1981); Universidade Loyola - Nova Orleans- USA (1981); PUC de São Paulo - Brasil (1982); Santa Úrsula - Rio de Janeiro - Brasil (1982); West Harford - USA (1983); Universidade Católica de Pernambuco - Recife - Brasil (1983); Universidade de Santa Maria - Canadá 91984); Chicago USA (1984); Universidade Federal Rural de Pernambuco - Recife - Brasil (1984); Universidade Católica de Goiás - Brasil (1984); Universidade Metodista de Piracicaba - São Paulo - Brasil (1984); Universidade Federal de Pernambuco - Brasil (1985); Universidade Ottaviensis - Otawa - Canadá (1986); Universidade Católica de Santos - São Paulo (1987); Universidade Católica do Paraná - Brasil (1987); Universidade do Estado do Ceará - Brasil (1987); Universidade Federal do Pará - Brasil (1990); Universidade Federal do Ceará - Brasil (1990); Pontifícia Universidade Católica do Rio de Janeiro - Brasil (1991).

\section{Conclusão}

"É dificil falar de Dom Helder sem emoção, é impossivel ficar indiferente diante de seu testemunho".22

Na Mensagem que dirigiu, em 1994, ao movimento italiano Mãos Estendidas, Dom Helder dizia: "Não estamos sós. Por isso, não aceito nunca a resignação nem o desespero. Um dia, a fome será vencida e haverá paz para todos. A última palavra neste mundo não pode ser a morte, mas a vida! Nunca mais pode ser o ódio, mas o amor! Precisamos fazer com que não haja mais desespero e, sim, esperança. Nunca mais vençam as mãos enrijecidas contra o outro, e, sim, isso que o movimento de vocês valoriza: Mãos estendidas! Unidas na solidariedade e no amor para com todos". ${ }^{23}$

\section{Dom Geraldo Lyrio Rocha}

Presidente da CNBB

Arcebispo de Mariana

(Aula Magna de inauguração oficial do ano acadêmico da PUC-Rio, pronunciada por Dom Geraldo Lyrio Rocha, aos 27.03.09).

\footnotetext{
${ }^{22}$ OLIVEIRA, Pedro Rubens Ferreira - In Revista de Teologia e Ciências da Religião, n. 7, 2008, p. 3,

${ }^{23}$ BARROS, Marcelo - op. cit. p. 184
} 